\title{
sit \\ Reflections on the historical, epistemological, and social meaning of technoscience
}

Maria Caramez Carlotto

\section{Les vertiges de la technoscience:}

\section{façonner le monde atome par atome}

Bernadette Bensaude-Vincent

La Découverte

Paris, 2009, $228 \mathrm{pp}$.

"France sustains today the best organized and most outspoken philosophical-ideological contestation of the conflation of science with technology", according to historian of science and technology, Paul Forman, "in part because over the past three to four decades France has been the locus of the best organized and most outspoken philosophical-ideological advocacy of that conflation" (Forman, 2007, p. 6). The book under review, The dizzy heights of technoscience: shaping the world atom by atom, by the French philosopher, Bernadette Bensaude-Vincent (Professor of History of Science at Universidade de Paris I - Sorbonne), is an important contribution to this contemporary philosophical-ideological debate on recent changes of the science-technology relationship and, consequently, on the meaning of the concept of technoscience.

In this debate, there are deep divisions between those who maintain that there are no significant differences between science and other forms of knowledge, especially technological knowledge, and those who recognize the specificity of science as both epistemological perspective and institutionalized practice of research (cf. Forman, 2007; Shinn \& Ragouet, 2008). The book under review, however, like many other theoretical and empirical writings on the theme, cannot be easily fitted to one or other of these opposing poles. Bensaude-Vincent endorses the fusion of science and technology, ending up with a defense of the demystifying character of the concept of technoscience, and the necessity to surpass the dualisms of modern philosophical thought; but, she also criticizes many postmodernist ideas that often lie behind these views - she offers a postmodern position opposed to postmodernism.

In this review, I will critically discuss the main lines of the author's argument concerning: (1) the demystifying character of the concept of technoscience; (2) 
technoscience as representing a radical change in the epistemological project of modern science; and (3) the primacy of technoscience in relation to social theory.

\section{l IS TECHNOSGIENGE A DEMYSTIFYING GONGEPT?}

In the first part of the book, "Archeology of a new knowledge", Bensaude-Vincent sketches a version of the history of science of the 2oth century that is anchored in the reconstruction of key moments of the institutional organization of science in advanced countries. She rejects as ideological views that divide this history into two distinct "ages": a first "age", in which science develops as an activity entirely "purified" from technology and from interests and values; and a second, when science is "corrupted" by the interests and values of war and industry and merges fully with technological developments. Different "ideal types" have been used to explicate such "ages" by various authors, e.g., Gibbons et al. (1994), and Etzkowitz and Leydesdoff (1997). BensaudeVincent (in conformity with others, such as Shinn, 2002; Godin, 2004; Callon, 2006) interprets these "ideal types" as performative concepts that correspond, not to empirically validated descriptions of reality, but to political projects for the organization of science that "embody value systems that currently guide research policy" (p. ${ }_{5}$ ). ${ }^{1}$ She also maintains that other dichotomies - "pure/applied", "disinterested/compromised" and "fundamental/applied" - serve ideological ends when they are used to idealize the science of the past, imputing to it a "purified" character.

Bensuade-Vincent aims to "demystify" accounts of the history of science that incorporate such dichotomizing idealizations by deconstructing the myths of "purified" science that completely obliterate the technological origin and dimension of scientific activity (p. 49 ff.). The controversial aspect of her analysis is the claim that the possibility of constructing a non-ideological history of science comes from the "demystifying concept of technoscience". Taking note of the constructivist origin of the concept of technoscience, she claims that it plays an essentially revelatory function:

Technoscience is a notion that made its name in a movement of reflexive and critical epistemology that consists in the shift of attention from the discourse to the practices of knowledge. Technoscience appeared, then, as a weapon in the battle against rhetoric, allowing the revelation of the realities hidden behind the clouds formed by a range of values that systematically undervalues technology for the benefit of science (p. 56).

1 Unqualified page references are of the book under review. 
I note at this point that the author does not offer an explicit argument for why the concept of technoscience per se is the bearer of this "demystifying spirit". The richness of her reconstruction of 2 oth century science lies in the concrete historical cases that she investigates when she takes the history of scientific disciplines - especially chemistry - as the object of her investigation. A demystifying perspective pervades her reconstruction, but it does not seem to be rooted in use of the concept of technoscience. Perhaps, then, it is Bensuade-Vincent, as historian of science, who is herself bringing in the demystifying perspective that she attributes to the concept of technoscience. What I am getting at can be seen by looking at her way of pointing to the pervasive role of technology in the history of chemistry. She presents case studies of how the specific sciences, during the processes of their formation and legitimation, attempt to erase their technological roots. One case involves the discursive construction of the dichotomy, "chimera pure" and "chimera applicata", as it is presented by Johan Gottschalk Wallerius in a $175^{1}$ Treatise. This dichotomy was deployed in a "purification" move, part of the effort to legitimate chemistry on the European university scene. Nevertheless, according to the author, this did not in fact mean that the discipline of chemistry was detached from industrial practices: "on the contrary, universities graduate more chemists; more jobs are created for chemists in agriculture, industry and health. The purity of science is an entirely ideological notion" (p. 51). Furthermore, the author argues more generally that chemistry, from its first beginnings, provided instances of the inseparability of science and technology, for chemistry does not build its objects from an Archimedean point that allows us to look at nature in its purity and based on detachment: "unlike naturalists who travel the world to practice their science outdoors, chemists and experimentalists in general need an enclosed entirely aseptic space to remake the nature and control their processes" ( $\left.p .5^{1}\right)$. Since chemistry fundamentally needs technology to construct its objects, in practice it is not marked by the ideology of purifying science from technology; according to Bensaude-Vincent, it is a laboratory science that exemplifies the validity of the concept of technoscience.

In the light of these historical reflections of the author, I question her claim that it is the concept of technoscience that serves to reveal the connection between science and technology, and suggest instead that it is her historical reconstruction of concrete institutional disputes, research practices and epistemological perspectives of, specifically, the discipline of chemistry. More explicitly, since the concept of technoscience has built into it the fusion of science and technology, it does not serve as a good instrument to get at how science and technology were related to each other in different concrete historical contexts. It is empirical research on the historical organization of science and technology that can reveal the complex relations between them that change with historical moment, social context and specific discipline. It is interesting to note 
that by projecting onto the concept of technoscience a "revealing power" that actually belongs to empirical research on history of science and technology, Bensaude-Vincent herself makes a move that the constructivist tradition has always criticized: projecting a discourse about science (the discourse of technoscience) as the concrete reality of its functioning.

In this context, Bensaude-Vincent points out that the scientific researchers, who are the main actors of technoscience, tend not to use the term "technoscience" at all. According to her, what is referred to by "technoscience" "is neither an institutional reality nor a political objective (...) it remains confined to the sphere of human sciences" (p. 12). That means that, at least as a "native category", the dichotomy science/ technology remains valid. For those who consider the categories of understanding and classification of the world to be structural elements of social reality, this is a striking observation. This is especially so, since during the 197 os the constructivist school completely changed science studies by developing a research agenda (of which ethnography in the laboratory is the paradigmatic example) that, focusing on the concrete practices of the researchers, shows the ideological character of perspectives that do not separate the dimensions of discourse about science from its concrete functioning. The author's observation, however, highlights that her analysis of science and technology, although purportedly a constructivist analysis, fails to treat separately the dimension of discourse about science from that of concrete scientific practices and their concrete functioning.

\subsection{SGientific AND TEGHNOLOGIGAL GONVERGENGE}

The tendency not to keep the two dimensions separate is also manifested, to some extent, in the way Bensaude-Vincent deals with the notion of "scientific and technological convergence". The "convergence" ideal postulates that the recent developments of nano, bio, information and cognitive sciences enable an unprecedented synergy that could unify science based on the most basic units of nature: atoms, genes, bits and neurons. This ideal was made popular in the beginning of 2000 s when the U.S. National Science Foundation launched its famous report, "Converging technologies for improving human performance" (see Bensaude-Vincent, 2012, for details). Since then, policies have been introduced in many countries to encourage research in which traditional specialized disciplines are supposed to be replaced by new unified scientific fields. Bensaude-Vincent recognizes the discursive character of the notion of convergence, that it expresses a political project for science that intends - like programs that encourage inter-, multi- and transdisciplinarity - to deconstruct scientific discipli- 
nes as spaces of relative autonomy for the production and certification of knowledge. The objective of the convergence program is to substitute the disciplinary system by a teleological project for science, in which the production of knowledge responds to politically defined practical goals (p. 5 o ff.).

However, before any conclusions can be drawn about the effects of convergence of science and technology on society, the following questions need to be addressed. How and to what extent has the project for scientific convergence been concretely implemented? What are the precise mechanisms that make the convergence project viable? Is convergence nowadays a reality that scientists have accommodated to in their research practices, or a political project that they resist? Some evidence suggests that convergence should be looked at mainly as a discourse or a project, and not as an already accomplished reality or inexorable tendency.

In Brazil, e.g., it appears that convergence is not yet an accomplished reality, although there are strong pressures to make it so. Mihäil Roco (the principal author of the US NSF Report on converging technologies) visited São Paulo in November, 2011 aiming to "motivate Brazilian researchers to work together with colleagues from other areas in large, ambitious, scientific, economic and social high-impact projects" (Fapesp, 2012, p. 48). But, although he has claimed that convergence is an inexorable trend (cf. Bensuade-Vincent, 2012), in São Paulo, he seemed to have changed his mind, for he stated: "it is not easy to convince a scientist to really take seriously what a colleague from another area is doing. One of my tasks is to take the scientists away from the inertia in which they live and show that they can earn a lot by working with specialists from other areas" (Fapesp, 2012, p. 48).

It seems that there exists a big gap between the project for scientific/technological convergence, and the concrete practices of many researchers who continue to work within their disciplinary traditions. The convergence project, therefore, should be treated as a discourse - or mainly as a discourse; and the process of building or producing convergence, as well as all the other elements of what authors call "technoscience", should be treated as a privileged research object, and not as a stabilized reality.

\section{TEGHNOSGIENGE AS REPRESENTING A RADIGAL GHANGE}

\section{IN THE EPISTEMOLOGICAL PROJEGT OF MODERN SGIENGE}

In the the second part of her book, "A world without borders", Bensaude-Vincent explores the thesis that technoscience represents a radical change in the epistemological project of modern science: 
It is undeniable that technoscience changed our vision of nature and our way of dealing with it. Even when the research objectives are cognitive and not technological (...) the questions addressed to nature have changed. Instead of "why?", one asks "how does it work?" (p. 117).

This thesis draws support from the analysis (in $\S 1$ above) of the transformation of the disciplinary organization of the production and certification of scientific knowledge into a model based on projects or problems (where collaboration from different areas is indispensable) aiming to realize well-defined and politically determined objectives. This analysis is now continued and deepened, and additional elements are provided to support the thesis. The author examines the cultural and cognitive meanings of the technoscientific project insofar as it aims to increase the performance capabilities of human beings and material objects to the point of overcoming the limits set by nature and the human condition. We confront here the problem - important to postmodern thought - of the end of nature. Nevertheless, based on an exposition of the modern conception of nature, Bensaude-Vincent argues that it is not reference to the "natural" that disappears in the midst of technoscience, but the specific concept of nature forged by modern science, the science of "Galileo, Descartes, Boyle and Newton". This science, aiming to emancipate itself from political and religious powers, conceived of nature as a reality, preceding and completely independent of any relationship with culture and values, which can be observed from an external point of view that is neutral and free from interests and values, and which is to be understood by reference to general laws and represented in universally valid theories. According to the author, this "disenchanted" nature was thus invented by modern science at the price of separating human subjects from nature: "the desire to access the hidden order under the sensible appearances puts the subject of knowledge outside of nature" (p. 114).

Bensaude-Vincent identifies, at the core of the epistemological rupture between modern science and contemporary technoscience, three changes that characterize the new vision of nature: (1) operationalism, (2) eliminating the separation between man and nature, and (3) concerning the status of individual objects and how they are individuated.

\subsection{Operationalism}

The trend of technoscience that the author calls "operationalism" involves emphasizing the uses of the objects of knowledge for practical or instrumental ends, thus emphasizing control of the conditions (and the technical instruments needed for it) for human intervention on and with these objects, rather than on understanding the laws 
and tendencies of their behavior in nature. Operationalism is, therefore, inextricably linked to the project for domination of nature.

As the author points out, however, the domination of nature is not new; it is at the core of the project of modernity, not a postmodern innovation. Adorno and Horkheimer, e.g., recognize its role in the science of the seventeenth century: "For Bacon as for Luther, "knowledge that tendeth to satisfaction is but a courtesan, which is for pleasure, and not for fruit or generation'. Its concern is 'not satisfaction which men can call truth', but 'operation', the effective procedure" (Adorno \& Horkheimer, 2002, p. 2). Likewise, Hugh Lacey cites Francis Bacon as a spokesman of the modern perspective of control, which maintains a direct relationship with the materialist strategies that are hegemonic in modern scientific research (Lacey, 2008, p. ${ }_{1} 3 \mathrm{ff}$.). At the same time, these authors recognize that modern science, by having direct dialogue with the modern perspective of control, does not abandon the epistemological project of science. Instead of an epistemological rupture occasioned by technoscience, then, we are maybe facing a continuity: rather than "how does it work?" replacing "why?" as the core question, we see both questions, in interaction, as central to the unfolding of modern science.

\subsection{The END OF THE SEPARATION BETWEEN MAN AND NATURE}

The second aspect that Bensaude-Vincent identifies of the epistemological rupture occasioned by technoscience is the immersion of the subjects of knowledge in their objects. "The posture of the observer outside the world who seeks an ideal objectivity, a vision 'from nowhere', is substituted by the posture of a researcher immersed in the world to be deciphered" (p. 120). This "immersion" implies a rupture "with the dominant epistemology in the twentieth century" that, while recognizing the limits of human understanding, was still deeply concerned with "the real"; but "technoscience (...) is indifferent to external reality" (p.121). From this perspective, the values of understanding and objectivity are lost as a consequence of the deconstruction of the Archimedean point of view, where science was supposed to be free of interests and values. Now, the paradigmatic examples are images and simulation models that function as "animated substitutes" of nature: "the images do not refer back to a 'beyond', to an exterior that they represent more or less schematically, they are, instead, self-referential" (p. 121).

I suggest that the idea of an epistemological rupture occasioned by technoscience, based on observer immersion, be treated as a hypothesis that needs further investigation. Other authors, who have investigated contemporary uses of images and simulations in science, have concluded that they serve as vehicles for new scientific 
questions, specifically "for the exploration of the form of physical objects and for the determination and comprehension of coercive forces that condition and limit the expression of a particular form in a physical system" (Marcovith \& Shinn, 2011, p. 231). For them, unlike Bensaude-Vincent, images are not "self-referential"; they serve to analyze an "outside" that remains the privileged object of investigation. Moreover, it is not clear why the immersion of the subjects of knowledge in their objects, and the consequent recognition that science is the bearer of interests and values, necessarily implies an abandonment of the ideal of objectivity. As shown by Lacey (2008), modern science, largely characterized by the materialist strategies of research which abstract from the human and ecological contexts of the objects investigated, is imbued with social values, notably the value of control; but that does not mean the absence of proper cognitive aims (cf. Lacey, 2008, p. 196). To recognize that the subject of knowledge is part of the object - contextualized in nature or society - that researchers want to investigate does not imply abandoning the ideal of objectivity.

\subsection{The STATUS OF INDIVIDUAL OBJEGTS AND HOW OBJEGTS ARE INDIVIDUATED}

The third and final change that characterizes the epistemological rupture occasioned by technoscience concerns the status of individual objects and how they are individuated: "while modern science seeks to enter into an order governed by general laws, in which each particular case is a species or a sample, technoscience isolates individual entities" (p. 122). Their individuation is mediated by technology: the object is inseparable from the devices that produce it; no longer is it nature that is observed on the computer screen, but objects produced by devices. A new conception of nature emerges from this development of technoscience, one that is even more dependent on the modern conception of control. Nature becomes turned into the field of possibilities illustrated by the discussions of nanotechnology and synthetic biology in the book. This implies a plastic conception of nature that is portrayed as simultaneously the source of inspiration, of legitimation and of tools for the domination of nature: "Nature is here invoked as that which 'authorizes' a technical project in a double sense: it makes the project actually possible and it grants permission for it to be done" (p. 129). Nature as "pure plasticity" paves the way for the emergence of a "world without limits", where there are "no limits to what is possible" (p. 146). Characterized in this way, technoscience certainly seems to represent a rupture with, rather than a deepening of, the modern project of science.

Bensaude-Vincent goes beyond this idea of technoscientific rupture with the modern project. According to her, this "world without limits" is also a world in which all the most fundamental oppositions that structured modern thought - science/tech- 
nology, man/machine, natural/artificial-become obsolete. But against post-modernist enthusiasm with this "flat world", the French philosopher assumes a critical position maintaining, that by abolishing all essential differentiations, technoscience ends up also abolishing the conflicts and tensions needed for harmony of social life. Her solution, which goes beyond both the modern affirmation of fundamental dichotomies and the post-modern evocation of the end of any differentiation, involves the idea that the differences should be defined not by dichotomous relationships, but by a tripartite one or what Bensaude-Vincent calls

a triangle of gold: nature, artifice and culture - none of these three terms has a definite sense a priori, they are defined by their relationships (...) they are poles of reference in an ongoing process that is constantly renewed. (...) Nature, artifice and culture are not factual data (...) on the contrary, they are objects of permanent contestation" (p. 148-50). [So], (...) the figure of the triangle allows one to shape a flat world, in the sense that no sacred or transcendental value is evoked. It is a horizontal world where everything is relative, because the referents are constructed by their relations that are being always reset" (p. 151).

This way of looking at things is compelling, if one accept the rupture between science/technoscience and the dichotomy modern/postmodern that it presupposes. It perhaps would be interesting, however, to reevaluate these dichotomies in the light of the idea of the persistence of modernity.

\section{THE PRIMACY OF TEGHNOSGIENGE IN RELATION TO SOCIAL THEORY}

In the last part of the book, "Questions of governance", Bensaude-Vincent focuses on the problem of governing or regulating technoscience. The general idea is to demonstrate how the imperative of control that guides the technoscientific enterprise ends up to abolishing all limits to the human "management" of nature, including its most elementary elements, like atoms and genes. But, the unexpected result of abolishing all limits to human control is that it has become more and more difficult, sometimes even impossible, for human beings to actually exercise control. This difficulty or impossibility, the author maintains, lies in the fact that these elementary objects of nature are inherently resistant to human control: we can't manage completely the atomic dimension or the genetic level. In the same vein, atomic and genetic engineering produce what Bensaude-Vincent, following Bruno Latour and Donna Haraway, calls hybrid objects or natural machines: "abundant and emerging natural sculptures neither 
natural nor entirely artificial" (p. 145). The problem is that "all those hybrid beings circulate as information on wireless networks, all available for capturing and ignoring barriers such as national borders" (p. 145). So, the search for maximum control over nature, which leads human beings to investigate the most elementary natural dimensions, results in the impossibility of control and confinement.

Bensaude-Vincent makes a very interesting assessment of the various efforts that have been made to address the social regulation of technoscience: ranging from attempts within the scientific community (beginning in the 1970s) to create self-regulatory mechanisms, to innovative social proposals for the shared construction of knowledge, including those aimed at strengthening scientific ethics (p. 163 ff.; see also Bensaude-Vincent, 2012). But these efforts towards the social control of technoscience have become more complicated in the light of social changes brought about by technoscience itself, by what Bensaude-Vincent calls the "biologization of politics": "The biopower of the 21st century concerns 'life itself'. It involves a new way of conceiving life, as a set of mechanisms that we can control and reconstruct at will (...) it transforms not only the sphere of politics but also that of nature" (p. 180).

This process limits the possibilities for social control of technoscience because it impinges on the very conditions for the possibility of politics as a space for shared decision making. At this point, the analysis enters the domain of social theory. Here, too, the author makes an important inversion: whereas, in the traditional sociology of science, social theory and its conception of society offer explanations of the functioning of science and technology, for Bensaude-Vincent it is technoscience that changes the conditions of the functioning of society. For her, it is technoscience that "explains" society and not the contrary. Is this inversion the work of society or of theory?

Acknowledgement: I wish to thank editor, Hugh Lacey, for his useful comments and corrections. However, I am solely responsible for any remaining problems in the article.

Maria Garamez Carlotto

Doctoral student, Doctoral Studies in Sociology, Scholarship from Fapesp,

Faculty of Philosophy, Letters and Human Sciences, Univesity of São Paulo, Brazil. mariacarlotto@usp.br 
REFLEGTIONS ON THE HISTORICAL, EPISTEMOLOGIGAL, AND SOGIAL MEANING OF TEGHNOSGIENGE

\section{REFERENGES}

Adorno, T. \& Horkheimer, M. The dialectic of enlightenment: philosophical fragments. Stanford: Stanford University Press, 2002.

Bensaude-Vincent, B. Nanotechnology: a new regime for the public in science? Scientiae Studia, 2012. This issue.

Callon, M. What does it mean to say that economics is performative? Papiers de Recherche du Centre de Sociologie de l'innovation, 5, p. 1-58, 2006.

Etzkowitz, H. \& LeydesdorfF, L. University and the global knowledge economy: a triple helix of universityindustry-government relations. London: Cassel Academic, 1997 .

Fapesp. Ponte entre as disciplinas. Revista Fapesp, 191, jan. 2012.

Forman, P. The primacy of science in modernity, of technology in postmodernity and of ideology in the history of technology. History and Technology, 23, 1/2, p. 1-152, 2007.

Gibbons, M. et al. The new production of knowledge: the dynamics of science and research in contemporary societies. London: Sage, 1994 .

Godin, B. The new economy: what the concept owes to the OECD. Research Policy, 33, p. 679-90, 2004.

Lacey, H. Valores e atividade científica 1. São Paulo: Associação Filosófica Scientiae Studia/Editora 34, 2008.

Marcovich, A. \& Shinn, T. Estrutura e função das imagens na ciência e na arte: entre a síntese e o holismo da forma, da força e da perturbação. Scientiae Studia, 9, 2, p. 229-65, 2011.

Shinn, T. Nouvelle production du savoir et triple hélice: tendences du prêt-à-penser las sciences. Actes de la Recherche en Sciences Sociales, 141, p. 21-30, 2002.

Shinn, T. \& Ragouet, P. Controvérsias sobre a ciência: por uma sociologia transversalista da atividade científica . São Paulo: Associação Filosófica Scientiae Studia/Editora 34, 2008. 